\title{
Egg numbers and fecundity traits in nine species of Mantella poison frogs from arid grasslands and rainforests of Madagascar (Anura: Mantellidae)
}

\author{
Giulia Tessa', Fabio Mattioli", Vincenzo Mercurio"I and \\ Franco Andreone ${ }^{\mathrm{IV}}$
}

\author{
Correspondence: \\ Franco Andreone \\ Museo Regionale di Scienze Naturali \\ Via G. Giolitti 36, 10123 Torino, Italy \\ E-mail franco.andreone@regione.piemonte.it
}

\begin{abstract}
The body size and number of eggs in dissected females were analysed in nine species of the Malagasy frog genus Mantella basing upon preserved specimens. These species were distinguished in terms of habitat and grouped as 'grassland species' (included $M$. betsileo, M. expectata, M. viridis), and 'rainforest species' (M. baroni, M. crocea, M. cowani, M. laevigata, M. nigricans, M. pulchra). The species with the lowest egg-number was $M$. cowani with a mean egg number of $37 \pm 15$, while the species with the highest egg-number was M. viridis with 115 \pm 21 eggs. In general, the grassland species are characterised by a higher number of relatively small eggs. Moreover, their fecundity was positively and significantly correlated to female body size. Rainforest species were smaller in size and with a lower number of eggs. We interpreted these differences as possible consequences of habitat adaptations. Among the studied species, the Critically Endangered Mantella cowani is also featured by a low number and large size of eggs. This is likely correlated with the high elevation site of the central highlands where this species occurs.
\end{abstract}

\section{RÉSUMÉ}

Dans cet article, nous présentons des informations portant sur la taille et le nombre d'œufs de neuf espèces de grenouilles de Madagascar appartenant au genre Mantella, en nous basant sur l'analyse de spécimens muséologiques. Ces espèces ont été classées selon l'habitat dans lequel elles ont été récoltées en deux groupes qui sont les "Mantella de zones herbeuses», originaires de l'Ouest et du Sud (arides) de Madagascar (M. betsileo, M. expectata, M. viridis), et les 'Mantella de forêt pluviale' (M. baroni, M. crocea, M. cowani, M. laevigata, $M$. nigricans, $M$. pulchra). L'espèce présentant le taux de fécondité le plus bas est $M$. cowani, avec un nombre moyen d'œufs par ponte de $37 \pm 15$, tandis que l'espèce avec le taux le plus élevé est $M$. viridis avec $115 \pm 21$ œufs par ponte. Nous avons également testé si la fécondité observée chez les espèces étudiées était différente entre le groupe des espèces de zones herbeuses (appartenant toutes au groupe Mantella betsileo) et celui des espèces de forêt pluviale (appartenant à plusieurs lignées phylogénétiques). Il apparaît clairement que les espèces de zones herbeuses produisent un plus grand nombre d'œufs par ponte et que les œufs sont plus grands que ceux pondus par les espèces de forêt pluviale. De plus, il existe dans le groupe des espèces de zones herbeuses une corrélation significative entre le taux de fécondité et la taille corporelle des femelles. Par contre, les résultats sont plus hétérogènes pour les espèces de forêt. Les femelles de ce groupe présentent une taille corporelle plus réduite et il n'y a pas de corrélation claire entre le nombre d'œufs et la taille corporelle des femelles. Les différences constatées ont été interprétées et expliquées par les modes de vie distincts que présentent les espèces considérées, avec la production d'un plus grand nombre d'œufs Iorsque leur taille est réduite. En outre, les femelles de ces espèces présentent une taille corporelle plus importante; il a d'ailleurs été prouvé que le taux de fécondité des amphibiens est directement proportionnel à la taille des femelles. Nous pouvons formuler l'hypothèse qu'il est plus avantageux pour les Mantella de zones herbeuses de produire le maximum d'œufs dans un nombre limité d'événements reproductifs, qui seraient rares et localisés. Ces résultats confirment également que les Mantella de forêts pluviales sont probablement plus sensibles aux altérations de I'habitat, qui est plus stable que celui des espèces de zones herbeuses. Dans ce contexte, nous considérons que l'espèce $M$. cowani peut être classée comme espèce en danger critique d'extinction. Cette espèce particulière de grenouille se présente comme la plus menacée parmi les espèces de la forêt pluviale du fait qu'elle produit un nombre limité d'œufs de taille relativement importante. L'espèce est ainsi probablement plus sensible que les autres Mantella aux altérations environnementales et à la collecte d'individus pour le commerce d'animaux.

KEYWORDS: Amphibians, arid habitats, ecology, fecundity, Madagascar, rainforests.

MOTS CLEF : amphibiens, écologie, fécondité, forêts pluviales, Madagascar, zones herbeuses.

Museo Regionale di Scienze Naturali, Via G. Giolitti, 36, 10123 Torino, Italy. Phone: +39 0114326306

Acquario di Genova, Area Porto Antico, Ponte Spinola, 16128 Genova, Italy. Phone:+39 0102345210

Forschungsinstitut und Naturmuseum Senckenberg, Sektion Herpetologie, Senckenberganlage 25, 60325, Frankfurt a.M., Germany.

Phone: +496917428153

v Phone: +390114326306 


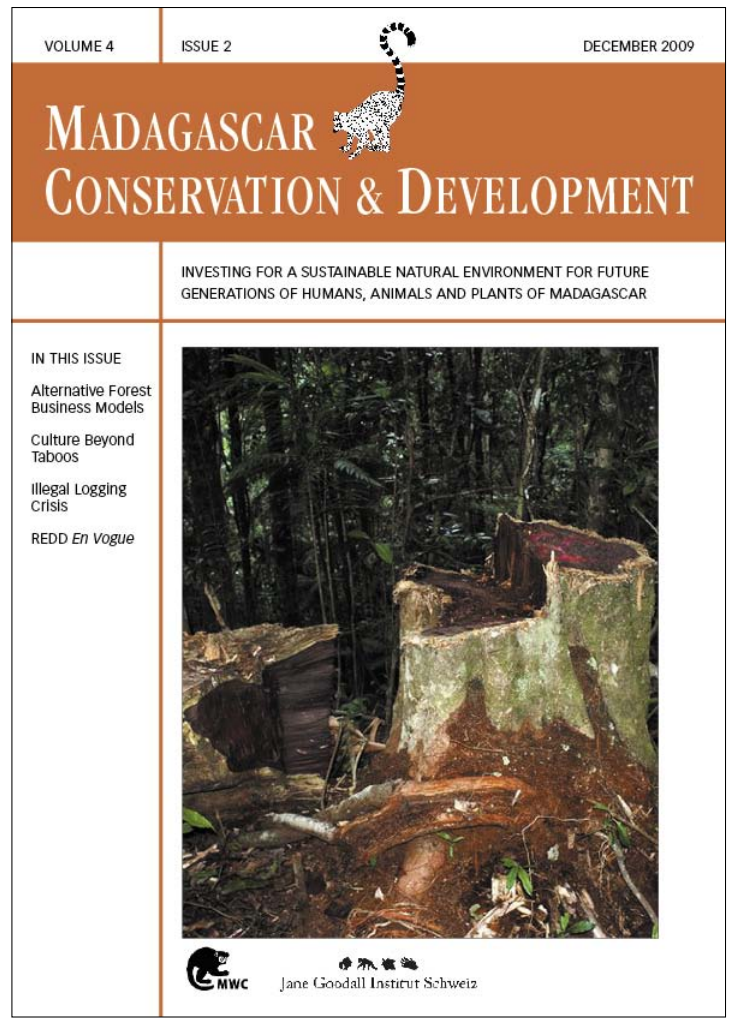

Madagascar Conservation \& Development is the journal of Madagascar Wildlife Conservation (MWC) and the Jane Goodall Institute (JGI Switzerland). It is produced in these institutions' own responsibility.

All the Issues and articles are freely available at http://www.mwc-info.net/en/services/journal.htm

Contact Journal MCD

info@journalmcd.net for general inquiries MCD funding@journalmcd.net for supporting the journal

Journal Madagascar Conservation \& Development Institute and Museum of Anthropology University of Zurich

Winterthurerstrasse 190

$\mathrm{CH}-8057$ Zurich, Switzerland

contact@mwc-info.net for general inquiries

Postfach 2701

CH-8021 Zürich, Switzerland

Logement 11, Cité Andohaniato

Antananarivo 101, Madagascar

info@janegoodall.ch for general inquiries JG

$2 \pi \approx$

Jane Goodall Institut Schweiz
Jane Goodall Institute Schweiz

Postfach 2807

8033 Zürich

switzerland 


\section{INTRODUCTION}

The large island of Madagascar has more than 240 described species (Glaw and Vences 2007) and 150-200 identified but not yet described species of amphibians (Vieites et al. 2009) Of these, the genus Mantella is particularly striking, and it includes probably the best-known frogs of Madagascar (Vences et al. 1999a, Jovanovic et al. 2006). Almost all the 16 Mantella species currently known show an impressive and attractive aposematic colouration, are diurnal, accumulate toxic alkaloids in the skin (Daly et al. 1996, Vences et al. 1998, Clark et al. 2005), and are actively searched for the international pet-trade (Mattioli et al. 2006, Andreone and Randriamahazo 2008a). The Mantella individuals exported every year sums up to at least 30,000 , and represent a large proportion of the amphibian and reptile trade of Madagascar (Rabemananjara et al. 2008). For this reason the whole Mantella genus is included in the CITES Appendix II, and three species (M. cowani, M. milotympanum, and $M$. aurantiaca) are currently classified by IUCN red list as Critically Endangered (CR), and four as Endangered (EN) (Andreone et al. 2005, 2008a,b).

One of the major tenets of the ongoing of the recently launched conservation plan for the amphibians of Madagascar (Andreone and Randriamahazo 2008b) is the constant monitoring of the species collected for the pet-trade, with regulation of the exportation quotas annually established by Malagasy authorities. In such a context, it is crucial to accumulate data on species' life history traits that may provide robust indications on their ecological sensitivity and vulnerability, supporting the decision-making process for assessing export quotas.

Among the life history traits, maximum longevity and mean fecundity are important parameters in assessing the potential extinction risks (Andreone et al. 2008a,b). Surprisingly, although several Mantella species are frequently raised in captivity (Andreone et al. 2006, Mattioli et al. 2006), comparatively little is known about the eggs that they lay. Within the Mantella species, $M$. laevigata shows the most strikingly different reproductive pattern, since females lay single large eggs in a tree-hole above the water level and parental care with egg-feeding was observed (Heying 2001). The remnant species show a more generalised reproduction mode, with egg-clutches laid on the ground outside water, next to forest streams or stagnant pools (Glaw et al. 2000, Glaw and vences 2007). Moreover, data on egg-number provided by terrarium books (e.g., Staniszewski 2001) and websites often refer to individuals kept in captivity that are only partly comparable to those from wild populations, because conditions (e.g. temperature, humidity, feeding availability) may easily be very different to those found in nature Thus, we are convinced that data on individuals captured in the wild are very important, and could provide useful information to unveil the species ecology.

Clearly, a further and non-negligible problem for conservation management is how to gather basic ecological information, especially considering that large number of the studies carried out on Malagasy amphibians are still focussed on the taxonomy and biodiversity assessment. This is logical, taken into account the extraordinary rate of species discoveries (Vieites et al. 2009). Given these constraints, we forecast that several years will be necessary to provide information on ecological traits for even a small fraction of the threatened species of Madagascar. Here, we strongly advocate the use of an important available reservoir of biological data, which are the preserved specimens housed in natural history museums. These vouchers can be utilised for several finalities, including studying their feeding habits, the pathogenic assessment, genetics, anatomy, reproduction, and age structure. The use of preserved museum vouchers as a source of biological data is not only useful, but also ethically relevant, since it does not involve obtaining data from live animals in the wild, and therefore maximises the amount of information that can be gathered from already dead animals (Andreone and Gavetti 2000).

In the present paper we provide original data on the egg-numbers and egg-size obtained by dissecting individuals of nine Mantella species. Our aim is to present not only basic information, but also to analyse the difference in traits between species inhabiting rainforest habitats and species from open environments, in order to provide useful tools for conservation management.

\section{METHODS}

We analysed nine Mantella species: Mantella baroni, M. betsileo, M. cowani, M. crocea, M. expectata, M. laevigata, M. nigricans, M. pulchra, and M. viridis (Figure 1, Table 1). Due to ongoing phylogenetic works there are some uncertainties on the taxonomic status of some of the studied species. The individuals from Isalo here attributed to $M$. betsileo (according to Crottini et al. 2008), have been considered as M. sp. aff.expectata 'South' by Glaw and Vences (2007). The individuals here attributed to $M$. crocea (according to Glaw and Vences 2007) were considered as M. cf. milotympanum by Bora et al. (2008).

The studied vouchers are currently held in the collections of Museo Regionale di Scienze Naturali, Torino (MRSN) and Parc Botanique et Zoologique de Tsimbazaza, Antananarivo (PBZT). As a standard technique, the frogs were captured in nature and euthanised by immersion in an anaesthetic solution (MS222 or chlorotone), then fixed in $4 \%$ formalin or $90 \%$ ethanol, and finally stored in ethanol $65 \%$.

The specimens come from the following localities: (1) Antoetra Plateau (Farihimazava, Vohisokina; administrative details, elevation and coordinates available in Andreone et al. 2007); (2) Antongombato area (Ambodimanga, Ambovomany, Andohenimangoko, Anketrabe, Anosiravo, Antomboko, Maleja, Mahatsinjo; Mercurio and Andreone 2008); (3) Fierenana Forest (Randrianirina 2005, Bora et al. 2008); (4) Isalo Massif (Antoha, Kazofoty, Tsitorina, Zahavola; Mercurio et al. 2008); (5) Masoala Peninsula (Ambaravato, Ambatoledama, Andasin'i Governera, Beanjada, Mahalevona, Menamalona, Nosy Mangabe; Andreone and Luiselli 2003), (6) Ranomafana (Mangevo; Vieites et al. 2009), (7) Tsaratanana Massif (Marovato; Andreone et al. 2008b), (8) Tsararano Massif (Antsarahan'ny Tsararano; Andreone and Luiselli 2000); (9) Vohimanana Forest (Vallan et al. 2004). Collectors and capture data are given in Appendix I.

Sexes were distinguished after analysis of secondary sexual characters and/or specimen dissection. As a general rule, males of the genus Mantella differ from females in being smaller and with more evident femoral glands (Glaw and Vences 2007). Moreover, in some species (i.e. those of the $M$. betsileo group, M. pulchra, and M. crocea) males have a horse-shoe shaped spot on the lower jaws (Glaw and Vences 2007). Totally, 96 adult females and 112 males were measured by a single person (GT) for their snout-vent length (SVL, precision at $0.1 \mathrm{~mm}$ ). Additional 

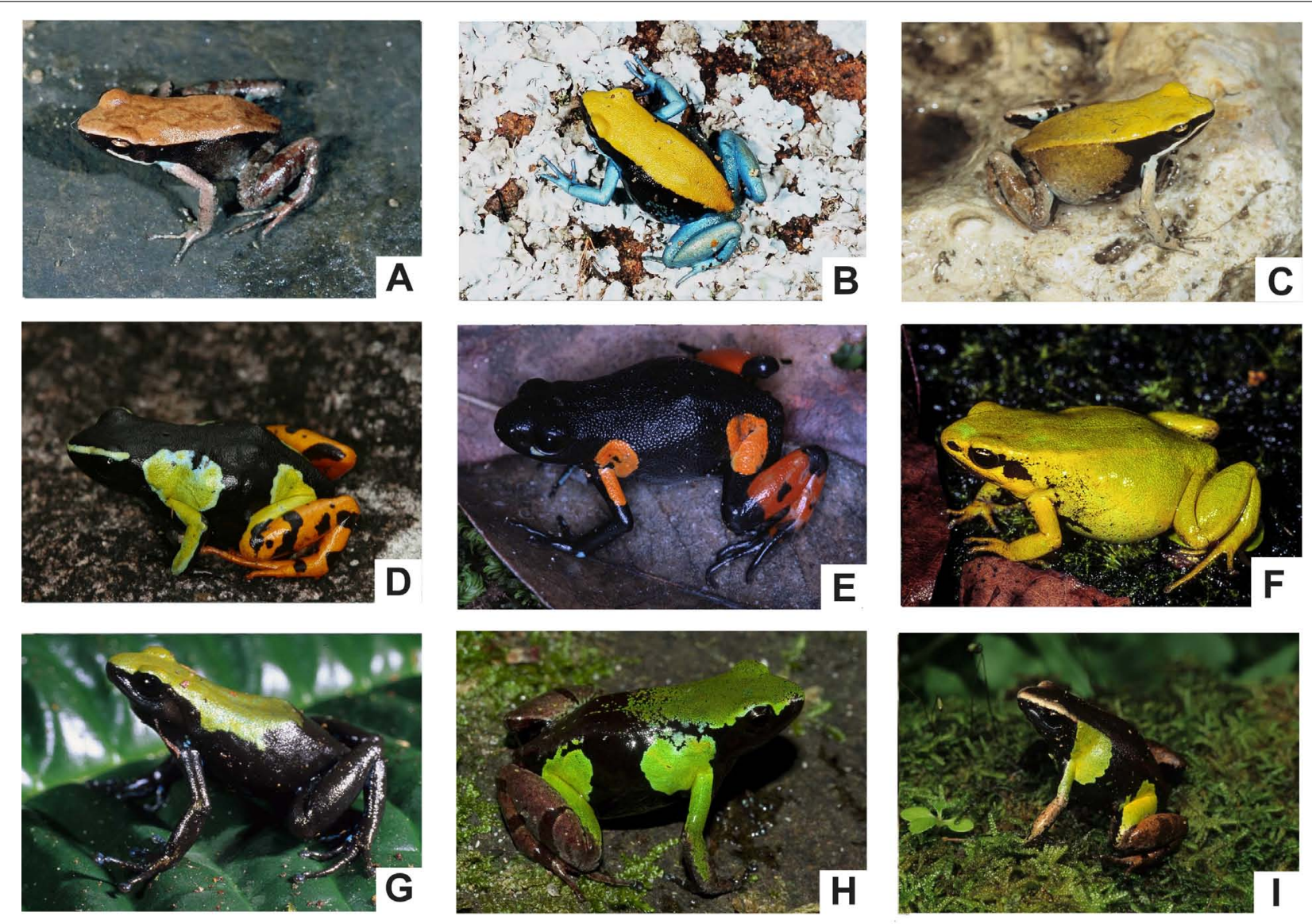

FIGURE 1. The nine Mantella species analysed in the paper. (A) M. betsileo (Isalo Massif); (B) M. expectata (Isalo Massif); (C) M. viridis (Antongombato); (D) M. baroni, (Antoetra); (E) M. cowani (Itremo); (F) M. crocea (captive individual without precise locality); (G) M. laevigata (Tsararano); (H) M. nigricans (Betampona); (I) M. pulchra (An'Ala / Vohimanana). All the photos are by F. Andreone, except for B and C (by V. Mercurio), F (by M. Vences) and H (by G. Rosa).

body size data were obtained from 29 individuals ( 9 females and 20 males), measured during fieldwork, but not taken as voucher specimens. Gravid females (52) were dissected by cutting longitudinally their belly. Then, ovaries were removed and mature eggs were counted under a binocular microscope.

The studied species were grouped according to their habitat preference as follows: (a) 'grassland species', with those species living in arid grasslands (Moat and Smith 2007), open habitats, and dry-deciduous forests ( $M$. betsileo, $M$. expectata, M. viridis), and (b) 'rainforest species', including species from the eastern rainforest slope, mainly inhabiting rainforest and nearby areas ( $M$. baroni, $M$. cowani, $M$. crocea, M. laevigata, M. nigricans, and M. pulchra).

Finally, we also measured the diameter (without jelly capsule) of the 20 largest mature eggs of each female. This measure is intended to give data on the mean size of mature eggs, and correlate it with the egg-number and body size.

\section{RESULTS}

Our data showed that the grassland Mantella species showed a relatively large $S V L$, ranging from $M$. betsileo (mean $\mathrm{SVL} \pm \mathrm{SD}$; males $=21.22 \pm 1.43 \mathrm{~mm}$; females $=23.87 \pm 0.87 \mathrm{~mm})$, to $M$. viridis (males $=25.88 \pm 2.11 \mathrm{~mm}$; females $=30.35 \pm 1.06$ $\mathrm{mm}$ ). The rainforest species showed a relatively higher level of SVL variability, with large-sized species like M. cowani (males $=25.67 \pm 1.66 \mathrm{~mm}$; females $=29.16 \pm 0.98 \mathrm{~mm}$ ) and $M$. baroni (males $=25.64 \pm 2.40 \mathrm{~mm}$; females $=28.65 \pm 0.97 \mathrm{~mm}$ ), and comparatively smaller species like $M$. crocea (males $=17.21 \pm$ $1.11 \mathrm{~mm}$; females $=20.07 \pm 1.25 \mathrm{~mm}$ ).

The pooled rainforest species were not significantly smaller $(\mathrm{SVL}=24.44 \pm 3.17 \mathrm{~mm}$; mean; $\mathrm{n}=6)$ than the pooled grassland species (SVL $=25.48 \pm 2.80 \mathrm{~mm} ; \mathrm{n}=3$; Student's t-test: $\mathrm{t}=0.50$, $\mathrm{p}=0.64$ ) (Table 1). Females were larger than males in both grassland (males $=23.66 \pm 2.34$; females $=27.31 \pm 3.26$ ) and rainforest species (males $=23.17 \pm 3.38$; females $=25.71 \pm 3.49$ ) . The species with the lowest egg-number was $M$. cowani, with a minimum of 20 eggs, while the species with the highest number was $M$. viridis, with a maximum of 167 eggs. The species with the smallest eggs was $M$. betsileo, with a mean diameter of 1.12 $\mathrm{mm}$, and the one with the biggest eggs was M. cowani, with a mean diameter of $1.87 \mathrm{~mm}$.

We also calculated the mean egg-number per species, and then we used these means to get a further mean for the two groups. The egg-number was higher in grassland species $(88.72 \pm 23.46 ; n=3)$ than in rainforest species $(45.91 \pm 9.27$; $n=6)$, although not significantly ( $t=3.04 ; p=0.08)$.

Finally, we analysed whether the relationship between egg-number and body size differed between grassland and rainforest species. We limited our comparison to species which showed non-different regression slopes: $M$. viridis and M. expectata (ANCOVA F $=2.302, p=0.153$ ) were used as representatives of grassland species, whereas $M$. baroni, M. cowani and $M$. nigricans (ANCOVA $F=1.537, p=0.329$ ) for rainforest species. For the other rainforest species we selected for the 
TABLE1. Data on habitat, habits, snout-vent length (SVL), and fecundity in the analysed Mantella species. For SVL, egg number and egg diameter, table shows mean $\pm S D$, range [minimum-maximum] and number of analysed individuals (n). The egg diameter column refers to the diameter of the 20 largest eggs selected from each dissected female.

\begin{tabular}{|c|c|c|c|c|c|c|}
\hline \multirow[t]{2}{*}{ Species } & \multirow[t]{2}{*}{ Habitat } & \multirow[t]{2}{*}{ Habits } & \multicolumn{2}{|c|}{ SVL (mm) } & \multirow[t]{2}{*}{ Egg number } & \multirow[t]{2}{*}{ Egg diameter } \\
\hline & & & Males & Females & & \\
\hline Mantella betsileo & Grassland & Terrestrial & $\begin{array}{c}21.22 \pm 1.43 \\
{[19.75-24.00]} \\
(11)\end{array}$ & $\begin{array}{c}23.87 \pm 0.87 \\
{[23.02-25.30]} \\
\text { (4) }\end{array}$ & $\begin{array}{c}73 \pm 18 \\
{[45-85]} \\
(4)\end{array}$ & $\begin{array}{c}1.12 \pm 0.19 \\
{[0.92-1.52]} \\
(80)\end{array}$ \\
\hline Mantella expectata & Grassland & Terrestrial & $\begin{array}{c}23.87 \pm 2.53 \\
{[21.00-31.30]} \\
(17)\end{array}$ & $\begin{array}{c}27.71 \pm 1.80 \\
{[24.40-31.70]} \\
(14)\end{array}$ & $\begin{array}{c}69 \pm 17 \\
{[42-86]} \\
(5)\end{array}$ & $\begin{array}{c}1.82 \pm 0.10 \\
{[1.68-2.03]} \\
(100)\end{array}$ \\
\hline Mantella viridis & Grassland & Terrestrial & $\begin{array}{c}25.88 \pm 2.11 \\
{[23.12-31.20]} \\
(20)\end{array}$ & $\begin{array}{c}30.35 \pm 1.06 \\
{[28.50-32.52]} \\
\text { (31) }\end{array}$ & $\begin{array}{c}115 \pm 21 \\
{[88-167]} \\
(11)\end{array}$ & $\begin{array}{c}1.81 \pm 0.09 \\
{[1.68-2.00]} \\
(220)\end{array}$ \\
\hline Mantella baroni & Rainforest & Terrestrial & $\begin{array}{c}25.64 \pm 2.40 \\
{[18.6-28.50]} \\
(15)\end{array}$ & $\begin{array}{c}28.65 \pm 0.97 \\
{[26.90-30.10]} \\
(14)\end{array}$ & $\begin{array}{c}42 \pm 8 \\
{[53-64]} \\
(7)\end{array}$ & $\begin{array}{c}1.64 \pm 0.12 \\
{[1.39-1.88]} \\
(140)\end{array}$ \\
\hline Mantella cowani & $\begin{array}{l}\text { Rainforest } \\
\text { altitude } \\
\text { grassland }\end{array}$ & Terrestrial & $\begin{array}{c}25.67 \pm 1.66 \\
{[22.30-28.90]} \\
(14)\end{array}$ & $\begin{array}{c}29.16 \pm 0.98 \\
{[27.90-31.40]} \\
(15)\end{array}$ & $\begin{array}{c}37 \pm 15 \\
{[20-57]} \\
(3)\end{array}$ & $\begin{array}{c}1.85 \pm 0.22 \\
{[1.59-2.37]} \\
(60)\end{array}$ \\
\hline Mantella crocea & Rainforest & Terrestrial & $\begin{array}{c}17.21 \pm 1.11 \\
{[14.78-19.51]} \\
\text { (13) }\end{array}$ & $\begin{array}{c}20.07 \pm 1.25 \\
{[18.30-21.58]} \\
(4)\end{array}$ & $\begin{array}{c}64 \pm 13 \\
{[47-75]} \\
(4)\end{array}$ & $\begin{array}{c}1.44 \pm 0.06 \\
{[1.38-1.60]} \\
(80)\end{array}$ \\
\hline Mantella laevigata & Rainforest & Semi-arboreal & $\begin{array}{c}24.25 \pm 0.51 \\
{[23.71-24.76]} \\
(5)\end{array}$ & $\begin{array}{c}25.97 \pm 1.19 \\
{[23.76-26.95]} \\
(5)\end{array}$ & $\begin{array}{c}41 \pm 11 \\
{[30-56]} \\
(5)\end{array}$ & $\begin{array}{c}1.81 \pm 0.14 \\
{[1.56-2.00]} \\
(100)\end{array}$ \\
\hline Mantella nigricans & Rainforest & Terrestrial & $\begin{array}{c}25.15 \pm 0.86 \\
{[24.11-26.01]} \\
\text { (5) }\end{array}$ & $\begin{array}{c}27.21 \pm 0.60 \\
{[26.55-28.35]} \\
(7)\end{array}$ & $\begin{array}{c}43 \pm 12 \\
{[22-55]} \\
(7)\end{array}$ & $\begin{array}{c}1.43 \pm 0.15 \\
{[1.10-1.70]} \\
(140)\end{array}$ \\
\hline Mantella pulchra & Rainforest & Terrestrial & $\begin{array}{c}20.62 \pm 2.10 \\
{[18.41-25.98]} \\
(13)\end{array}$ & $\begin{array}{c}23.21 \pm 1.79 \\
{[21.33-28.22]} \\
(12)\end{array}$ & $\begin{array}{c}48 \pm 9 \\
{[35-61]} \\
(6)\end{array}$ & $\begin{array}{c}1.82 \pm 0.15 \\
{[1.68-2.05]} \\
(120)\end{array}$ \\
\hline
\end{tabular}

analysis the three species of the same group ( $M$. cowani group) that show homogeneous characteristics. We explicitly excluded the species that had a different regression slope.

The regression slopes were significantly different between grassland and rainforest species (ANCOVA using body size as covariate, habitat as fixed factor, and egg numbers as dependent variable; $F=26.17, p<0.01$ ) (Figure 2). The log-transformed eggnumber was positively correlated with the log-transformed female body size in grassland species (Pearson's $r^{2}=0.74 ; p<0.01$ ). In rainforest species the egg-number remained rather constant in relation with the body size (Pearson's $r^{2}=0.27 ; p>0.05$ ).

A linear correlation between SVL / egg diameter and egg number confirmed the different trend; the egg-size in grassland species was constant as the egg-number increased (Pearson's $\left.r^{2}=0.00 ; p=0.99\right)$ whilst in rainforest species there is no correlation (Pearson's $r^{2}=0.09 ; p=0.22$ ).

\section{DISCUSSION}

These are the first data on fecundity of individuals collected in nature for nine species in the genus Mantella. Consistent information on fecundity here presented was obtained from specimens preserved in museums, which turn out to be a suitable method.

As already done with previous studies on egg-number in other Malagasy frogs (Vences et al. 1999b), the fecundity values here presented are based on counting mature eggs. We consider this number as the best available indicator of overall fecundity, since the eggs that will be laid during the reproductive season represent it. Depending on the egg-laying strategy the number of eggs per clutch may vary among species. Species from arid areas may concentrate the egg-laying in a few occasions (coinciding with the major rainfall events), while species from rainforests lay eggs in many events. For this reason egg-counting made in captivity or in the wild may provide numbers that do not reflect the real annual fecundity. In fact, available counting of eggs within clutches of $M$. betsileo (Kuchling 1993) and M. expectata (Mercurio et al. 2008) are hitherto much less than data here presented (respectively 35-40 eggs versus $73 \pm 18$ and $69 \pm 17$ eggs).

This technique has some caveats to be taken in mind. In fact, specimens used for the analysis were caught in different periods of the breeding season. So far, it would have been more convenient getting fecundity data from females collected at the beginning of rainy season, just after their latency period and before they lay the eggs. However, it is virtually impossible to get an unequivocal starting date of the reproductive activity: Climatic and geographic factors such as altitude, intensity of rain and temperature make the beginning of reproductive activity highly unpredictable. Thus, even for 


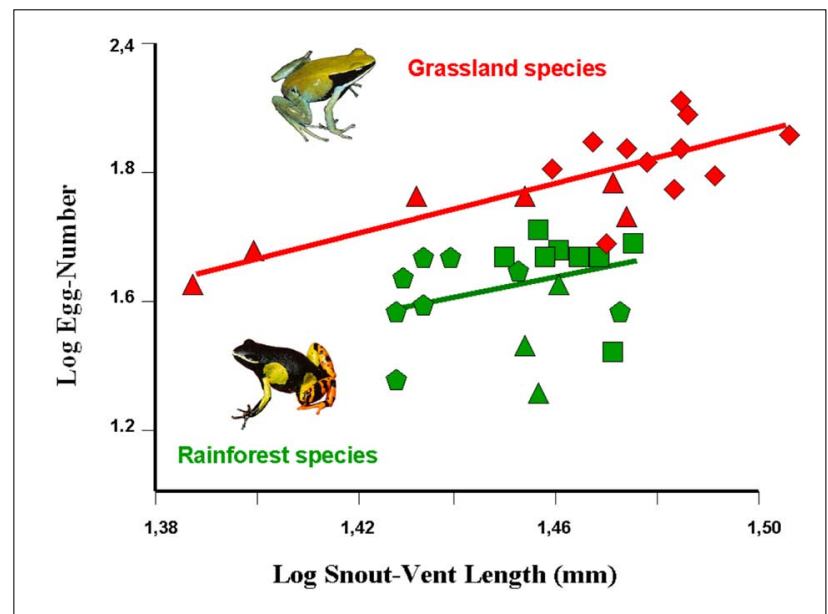

FIGURE 2. Relation between body size (SVL) and number of eggs in Mantella species from rainforest (red square: $M$. baroni; red triangle: $M$. cowani; red pentagon: $M$. nigricans) and grassland (green triangle: $M$. expectata; green rhombus: $M$. viridis) habitats. Rainforest species are symbolised by $M$. baroni and the grassland species by $M$. viridis.

animals captured at the beginning of the rainy season (i.e. in October), we cannot exclude that some females already laid the eggs, and/or that they have a reproductive period more extended than usually believed.

As an overall result, the grassland species had the highest number of eggs with the smallest diameter, while the rainforest species laid less and larger eggs. In two grassland species ( $M$. expectata and $M$. viridis) the female body size was positively associated with the egg-number. This suggests the existence of an ongoing selection to increase female body size, associated to a higher number of eggs. This relation is already known in many species, and it is assumed that it is one of the main causes for the sexual dimorphism in anurans (Halliday and Verrell 1986). The egg-number in the three rainforest species was less variable than in grassland species, ranging 20-75 eggs, and did not show such an evident correlation between female body size and number of eggs.

Our interpretation is that there is a relationship between the egg-number and egg-size with habitat types. Grassland species lay eggs in one or a few events, likely coinciding with occasional and seasonal rains, while rainforest species lay eggs at different times of the year. The number of eggs produced by Mantella from arid habitats is higher, in order to maximise their reproductive efforts. Our observations support the considerations provided by Wells (2007), who argued that a high egg-number and a comparatively small egg size are often features of species living in sub-desertic and seasonal low altitude habitats, where the water is temporary.

The differences in terms of body size are likely related, and females of Mantella from grassland environments generally have a larger body size, which is paralleled by a higher fecundity. Moreover, we cannot exclude that a large body size in grassland species may be an adaptation against desiccation in arid environments.

Finally, we stress the importance of fecundity and habitat in terms of species conservation, especially to estimate whether the collecting of individuals for pet-trade may represent a real threat, and to establish reliable exportation quotas (Andreone et al. 2006). Our opinion is that species with a higher fecundity and a rapid growth may respond better to collection than species inhabiting stable habitats and with a slower growth. For this reason, we believe that rainforest species, which are featured by an overall lower fecundity, are likely more prone and sensitive to habitat changes and collecting need a constant conservation effort. This is in accordance with considerations provided by Andreone and Luiselli (2003). Consequently, a more continuous monitoring action is recommended, as it is stressed in the action plan designed to assure a long-term conservation of Malagasy amphibians (Andreone and Randriamahazo 2008b).

These considerations find a further support by highlighting some aspects regarding the conservation status of the Critically Endangered Harlequin mantella, Mantella cowani (IUCN 2008). M. cowani is known only from a few altitude grassland habitats and moors of Madagascar's central highland and may be considered the most threatened frog species of the island (Andreone and Randrianirina 2003, Andreone et al. 2006).

Although it is obviously difficult to ascertain what the species' original habitat was, a recent finding of the species in a high altitude rainforest located on the Itremo Massif (Birkinshaw et al. 2004) indicates that $M$. cowani could be a montane rainforest species, and most likely the current occurrence in high-altitude grasslands and along streams running in open areas is a consequence of the deforestation of Madagascar's highlands. Among this group M. cowani appears as the most sexually dimorphic species, with a mean body size of $25.7 \pm 1.66 \mathrm{~mm}$ (males) and $29.2 \pm 0.98 \mathrm{~mm}$ (females). Moreover, it shows the lowest observed mean number of eggs $(37.33 \pm 15.04)$, and the largest mean egg-size $(1.85 \mathrm{~mm})$ though sampling is rather limited $(n=3)$. We suppose that the low number of voluminous eggs and the large body size observed are likely to be interpreted as traits of adaptation $M$. cowani to high altitudes, and are also features that limit the species capacity to recover in altered sites or after collection for the pet trade.

\section{ACKNOWLEDGEMENTS}

This study was done with the support from several organisations to which we are extremely grateful: ACSAM, Amphibian Specialist Group, Conservation International, EAZA, Gondwana Conservation and Research, Madagascar Fauna Group, Nando Peretti Foundation, Parc Botanique et Zoologique de Tsimbazaza, University of Antananarivo, Van Thienhoven Foundation, Wildlife Conservation Society, and World Wide Fund for Nature. We are especially indebted to the Malagasy authorities for the necessary permits and export authorisations. We thank C. Randrianantoandro for sharing with us information on the habitat of M. cowani, M. Vences and G. Rosa for kindly providing the photograph of $M$. crocea and $M$. nigircans, J. E. Randrianirina who accompanied us in the field, C. Angelini for fruitful discussions. J. Bielby revised the English language and L. Derussé made the French summary. Three referees and the editor greatly improved an early draft of this paper.

\section{REFERENCES}

Andreone, F. and Gavetti, E. 2000 Conservazione \& Conservazione: riflessioni sul significato del collezionismo erpetologico nei musei di storia naturale. In Atti del I Congresso Nazionale della Societas Herpetological Italica (Torino, 1996). C. Giacoma (ed.), pp 29-36.Museo Regionale di Scienze Naturali. Torino, Italy.

Andreone, F. and Luiselli, L. M. 2003. Conservation priorities and potential threats influencing the hyper-diverse amphibians of Madagascar. Italian Journal of Zoology 70, 1: 53-63. (doi: 10.1080/11250000309356496) 
Andreone, F. and Randriamahazo, H. 2008a. Essay 5.2. The endemic and threatened amphibians of Madagascar. In: Threatened Amphibians of the World. S. Stuart, M. Hoffmann, J. Chanson, N. Cox, R. Berridge, P. Ramani, B. Young (eds), pp 59-60. Lynx Edicions, IUCN, and Conservation International. Barcelona, Gland, Arlington.

Andreone, F., and Randriamahazo, H. 2008b. Sahonagasy Action Plan. Conservation programs for the amphibians of Madagascar / Programmes de conservation pour les amphibiens de Madagascar. Museo Regionale di Scienze Naturali, Conservation International, IUCN/ SSC Amphibian Specialist Group. Turin, Italy.

Andreone, F. and Randrianirina, J. E. 2003. It's not carnival for the harlequin mantella! Urgent action needed to conserve Mantella cowani, an endangered frog from the High Plateau of Madagascar. Froglog 59: 1-2.

Andreone, F., Cadle, J. E., Cox, N., Glaw, F., Nussbaum, R. A., Raxworthy, C. J., Stuart, S. N., Vallan, D. and Vences, M. 2005. Species review of amphibian extinction risks in Madagascar: Conclusions from the Global Amphibian Assessment. Conservation Biology 19, 6: 1790-1802. (doi:10.1111/j.1523-1739.2005.00249.x)

Andreone, F., Mercurio, V. and Mattioli, F. 2006. Between environmental degradation and international pet trade: Conservation strategies for the threatened amphibians of Madagascar. Natura - Società italiana di Scienze naturali e Museo civico di Storia Naturale di Milano, 95, 2: .81-96.

Andreone, F., Vences, M., Glaw, F. and Randrianirina, J. E. 2007. Remarkable records of amphibians and reptiles on Madagascar's central high plateau. Tropical Zoology 20, 1: 19-39.

Andreone, F., Carpenter, A. I., Cox, N., du Preez, L., Freeman, K., Furrer, S., Garcia, G., Glaw, F., Glos, J., Knox, D., Köhler, J., Mendelson III, J. R., Mercurio, V., Mittermeier, R. A., Moore, R. D. Rabibisoa, N. H. C., Randriamahazo, H., Randrianasolo, H., Rasoamampionona Raminosoa, N., Ravoahangimalala Ramilijaona, O., Raxworthy, C. J., Vallan, D., Vences, M., Vieites, D. R. and Weldon, C. 2008a. The challenge of conserving amphibian megadiversity in Madagascar. PLoS Biology 6, 5: e118. (doi:10.1371/journal.pbio.0060118)

Andreone, F., Cox, N. A., Glaw, F., Köhler, J., Rabibisoa, N. H. C., Randriamahazo, H., Randrianasolo, H., Raxworthy, C. J., Stuart, S. N., Vallan, D. and Vences, M. 2008b. Update of the Global Amphibian Assessment for Madagascar in light of species discoveries, nomenclature changes, and new field information. Malagasy poison frogs in the pet trade: A survey of levels of exploitation of species in the genus Mantella. In: A Conservation Strategy for the Amphibians of Madagascar. F. Andreone (ed.), pp 419-438. Monografie 45. Museo Regionale di Scienze Naturali, Torino.

Andreone, F., Glaw, F., Mattioli, F., Jesu, R., Schimmenti, G., Randrianirina, J. E. and Vences, M. 2009. The peculiar herpetofauna of some Tsaratanana rainforests and its affinities with Manongarivo and other massifs and forests of northern Madagascar. Italian Journal of Zoology 76, 1: 92110. (doi: 10.1080/11250000802088603)

Birkinshaw, C., Andriamihajarivo, T. H., Randrianaina, L., Randrianarivelo, C., Rasolondraibe, B., Andriamandrato, R. \& Razafindrasoa, R. 2004 Evaluation bio-écologique des ressources naturelles et pression anthropiques - études socio-économiques en vue d'établir une proposition de stratégie de conservation pour le Massif d'Itremo. Unpublished Report, the Missouri Botanical Garden, Antananarivo.

Bora, P., Dolch R., Jenkins R., Jovanovic O., Rabemananjara, F. C. E., Randrianirina J., Rafanomezantsoa, J., Raharivololoniaina, L., Ramilijaona O., Raminosoa N., Randrianavelona R., Raselimanana A., Razafimahatratra B., Razafindraibe T. and Vences M. 2008. Geographical distribution of three species of Malagasy poison frogs of high conservation priority: Mantella aurantiaca, $M$. crocea and $M$. milotympanum. Herpetology Notes 1: 39-48.

Clark V. C, Raxworthy, C. J, Rakotomalala, V., Sierwald, P. and Fisher, B. L. 2005. Convergent evolution of chemical defense in poison frogs and arthropod prey between Madagascar and the Neotropics. Proceedings of the National Academy of Sciences of the United States of America 102, 33: 11617-11622.

Crottini, A., Chiari, Y., Mercurio, V., Meyer, A., Vences, M. and Andreone, F. 2008. Into the canyons: The phylogeography of the Malagasy frogs Mantella expectata and Scaphiophryne gottlebei in the arid Isalo Massif, and its significance for conservation (Amphibia: Mantellidae and Microhylidae). Organisms Diversity \& Evolution 8, 5: 368-377. (doi:10.1016/j.ode.2008.08.001)
Daly, J. W., Andriamaharavo, N. R., Andriantsiferana, and Myers, C. W. 1996. Madagascan poison frogs (Mantella) and their skin alkaloids. American Museum Novitates 3177: 1-34.

Glaw, F. and Vences, M. 2007. A Fieldguide to the Amphibians and Reptiles of Madagascar. Third edition. Vences \& Glaw Verlag, Cologne.

Glaw, F., Schmidt, K., \& Vences, M. 2000. Nachzucht, Juvenilfärbung und Oophagie von Mantella laevigata im Vergleich zu anderen Arten der Gattung (Amphibia: Ranidae). Salamandra, 36: 1-24.

Halliday, T. R. and Verrell, P. A. 1986. Sexual selection and body size in amphibians. Herpetological Journal 1, 3: 86-92.

Heying, H. E. 2001. Social and reproductive behaviour in the Madagascan poison frog, Mantella laevigata, with comparison to the dendrobatids. Animal Behaviour 61: 567-577. (doi: 10.1006/anbe.2000.1642)

IUCN. 2008. 2008 IUCN Red List of Threatened Species. $<$ Www.iucnredlist.org> Accessed 19 May 2009

Jovanovic, O., Rabemananjara, F., Ramilijaona, O., Andreone, F., Glaw, F. and Vences, M. 2006. Frogs of Madagascar Genus Mantella. Pocket Identification Guide. Conservation International, Washington.

Kuchling, G. 1993. Zur Verbreitung und Fortpflanzung von Mantella betsileo in Westmadagaskar. Salamandra 29, 3-4: 273-276.

Mattioli, F., Gili, C. and Andreone, F. 2006. Economics of captive breeding applied to the conservation of selected amphibian and reptile species from Madagascar. Natura - Società italiana di Scienze naturali e Museo civico di Storia Naturale di Milano 95 (2): 67-80.

Mercurio, V. and Andreone, F., 2008. New distribution data of the green mantella, Mantella viridis, from northern Madagascar (Anura: Mantellidae). Herpetology notes, 1: 3-7

Mercurio, V., Aprea, G., Crottini, A., Mattioli, F., Randrianirina, J. E., Razafindrabe, T. J. and Andreone, F. 2008. The amphibians of Isalo Massif, southern-central Madagascar: High frog diversity in an apparently hostile dry habitat. In: A Conservation Strategy for the Amphibians of Madagascar. F. Andreone (ed.), pp 143-196. Monografia del Museo Regionale di Scienze Naturali 45, Torino.

Moat, J. and Smith, P. 2007. Atlas of the Vegetation of Madagascar. Kew Publishing, Royal Botanic Gardens, Kew.

Rabemananjara, F. C. E., Rasoamampionona Raminosoa, N., Ravohangimalala Ramilijaona, O., Andreone F., Bora, P., Carpenter, A. I., Glaw, F., Razafindrabe, T. J., Vallan, D., Vieites, D.R. and Vences, M. 2008. Malagasy poison frogs in the pet trade: A survey of levels of exploitation of species in the genus Mantella. In: A Conservation Strategy for the Amphibians of Madagascar. F. Andreone (ed.), pp 277-300. Monografia del Museo Regionale di Scienze Naturali 45, Torino.

Randrianirina, J. E. 2005. Nouvelles données sur la distribution d’une espèce de grenouille menacée dans la foret de Fierenana, Madagascar, Mantella milotympanum (Amphibia, Mantellidae). Bulletin de la Societé Herpetologique de France 115: 48-54.

Staniszewski, M. 2001. Mantellas. Edition Chimaira, Frankfurt am Main.

Vallan, D., Andreone, F., Raherisoa, V. H. and Dolch, R. 2004. Effects of low, selective wood exploitation on amphibians in a tropical rain forest in east Madagascar. Oryx 38, 4: 410-417. (doi:10.1017/S003060530400078X)

Vences, M., Glaw, F. and Böhme, W. 1998. Evolutionary correlates of microphagy in alkaloid-containing frogs (Amphibia: Anura). Zoologischer Anzeiger 236, 4: 217-230.

Vences, M., Glaw, F. and Böhme, W., 1999a. A review of the genus Mantella (Anura, Ranidae, Mantellinae): Taxonomy, distribution and conservation of Malagasy poison frogs. Alytes 17, 1-2: 3-72.

Vences, M., Glaw, F. and Zapp, C. 1999b. Bemerkungen zu Eizahlen und Eigrößen bei madagassischen Fröschen der Gattungen Tomopterna, Aglyptodactylus, Boophis und Mantidactylus (Amphibia: Ranidae). Salamandra 35, 2: 77-82.

Vieites, D. R., Wollenberg, K.C., Andreone, F., Köhler, J., Glaw, F., and Vences, M. 2009. Vast underestimation of Madagascar's biodiversity evidenced by an integrative amphibian inventory. Proceedings of the National Academy of Sciences of the United States of America 106, 20: 82678272. (doi: 10.1073/pnas.0810821106)

Wells, K. D. 2007. The ecology and behavior of amphibians. The University of Chicago Press, Chicago. 


\section{APPENDIX}

\section{APPENDIX I}

Specimens examined (MRSN = specimens housed in the Museo Regionale di Scienze Naturali, Torino; PBZT = specimens housed in the Parc Botanique et Zoologique de Tsimbazaza, Antananarivo). Abbreviations: FA = F. Andreone; $V M=V$. Mercurio; JER = J. E. Randrianirina; Prov. = Province; $I \mathrm{IM}=$ Isalo Massif; $\mathrm{MP}=$ Masoala Peninsula, $\mathrm{AA}$ = surroundings of Antongombato and Montagne des Français.

Mantella baroni - MRSN A2404, no precise locality data, I.2000; MRSN A2900 (Mangevo, Ranomafana, Fianarantsoa Prov., 10.II.1994, FA and VM), MRSN A2903 (Mangevo, Ranomafana, Fianarantsoa Prov., 10.II.1994, FA and VM), MRSN A2915 (no data), MRSN A2985 (Mahalevona, MP, Antsiranana Prov., 17.II.2002, JER); PBZT 739, no località data, I.2000; Mantella betsileo - MRSN A5231 (Tsitorina, IM, Fianarantsoa Prov., 3.XII.2004), MRSN A5238 (Tsitorina, IM, Fianarantsoa Prov., 3.XII.2004); MRSN A5232 (Antoha, IM, Fianarantsoa Prov., 3.XII.2004); MRSN A5239 (Kazofoty, IM, Fianarantsoa Prov., 2.XII.2004); Mantella cowani - MRSN A3203 (Farimazava, Antoetra, Fianarantsoa Prov., 31.I.2003, FA), MRSN A3206 (Farimazava, Antoetra, Fianarantsoa Prov., 31.I.2003, FA); MRSN A3208 (Vohisokina, Antoetra, Fianarantsoa Prov., 28.I.2003, FA); Mantella crocea - PBZT unlabelled, likely Fierenana; Mantella expectata - MRSN A5156 (Zahavola, IM, Fianarantsoa Prov., 24.XI.2004), MRSN A5168 (Zahavola, IM, Fianarantsoa Prov., 16.XI.2004), MRSN A5172 (Zahavola, IM, Fianarantsoa Prov., 16.XI.2004), MRSN A5180 (Zahavola, IM, Fianarantsoa Prov., 12.XI.2004), MRSN A5206 (Zahavola, IM, Fianarantsoa Prov., 24.XI.2004); Mantella laevigata - MRSN A2999 (Beanjada, MP, Mahalevona, Antsiranana Prov., 22.XI.1998); MRSN A3000 (Andasin'i Governera, MP, Mahalevona, Antsiranana Prov., 6.XII.1998); MRSN A4475 (Ambaravato, MP, Mahalevona, Antsiranana Prov., 4.XII.1999, FA); MRSN A4482 (Menamalona, MP, Mahalevona, Antsiranana Prov., 11.XII.1999, FA), MRSN A4505 (Menamalona, MP, Mahalevona, Antsiranana Prov., 11.XII.1999); MRSN A4506 (Menamalona, MP, Mahalevona, Antsiranana Prov., 11.IX.1999); Mantella nigricans - MRSN A4454 (Ambatoledama, MP, Mahalevona, Antsiranana Prov., 16.XI.1998); MRSN A4456 (Beanjada, MP, Mahalevona, Antsiranana Prov., 22.XI.1998, FA); MRSN A4484 (Marovato, Tsaratanana, Antsiranana Prov., 28.XII.2000, JER); MRSN A4526 (Nosy Mangabe, Maroantsetra, Toamasina Prov., 1.VI.1997, FA) MRSN A4528 (Antsarahan'ny Tsararano, Tsararano, Antsiranana Prov., 29.XI.1996), MRSN A4529 (Antsarahan'ny Tsararano, Tsararano, Antsiranana Prov., 29.XI.1996); Mantella pulchra - PBZT unlabeled (Fierenana, Toamasina Prov., I.2004); Mantella viridis - MRSN A5050 (Antomboko, AA, Antsiranana Prov., 21.I.05); MRSN A5055 (Ambovomany, AA, Antsiranana Prov., 15.I.2005); MRSN A5066 (Anosiravo, AA, Antsiranana Prov., 24.I.2005); MRSN A5088 (Antomboko, AA, Antsiranana Prov., 6.I.2005); MRSN A5090 (Anketrabe, AA, Antsiranana Prov., 5.I.2005); MRSN A5095 (Andohenimangoko, AA, Antsiranana Prov., 8.1.05); MRSN A5102 (Ambodimanga, AA, Antsiranana Prov., 17.I.2005); MRSN A5114 (Maleja, AA, Antsiranana Prov., 7.I.2005), MRSN AA5127 (Maleja, AA, Antsiranana Prov., 7.I.2005); MRSN A5117 (Andohenimangoko, AA, Antsiranana Prov., 15.I.2005); MRSN A5121 (Mahatsinjo, AA, Antsiranana Prov., 17.I.2005) 